\title{
Analyzing Geometry Misconception of Prospective Teachers Using Three-Tier Diagnostic Test
}

\author{
Sudi Prayitno* \\ Mathematics Education Study Program \\ Universitas Mataram \\ Mataram, Indonesia \\ s.prayitno@unram.ac.id
}

\author{
Arjudin Arjudin \\ Mathematics Education Study Program \\ Universitas Mataram \\ Mataram, Indonesia
}

\author{
Hapipi Hapipi \\ Mathematics Education Study Program \\ Universitas Mataram \\ Mataram, Indonesia
}

\begin{abstract}
The present descriptive study aims to analyze the misconceptions among prospective mathematics teacher on geometry using three-tier diagnostic tests. The research subjects were 52 students of mathematics education study program in a university in Mataram, Indonesia. The data were collected from students' written work in solving the three-tier geometry test. The test investigated the students' (1) understanding of concepts, (2) reasons, and (3) confidence in answering problems (1) and (2). Data analysis performed quantitatively and quantitatively using descriptive method. The results showed that there are: (1) $28.6 \%$ students who understood the concept, (2) $10.8 \%$ students who only guessed or were not sure of the answer and (3) $60.6 \%$ students had misconceptions. Misconceptions that occurred in students can be divided into three categories, namely: (1) pure misconceptions as much as $43.7 \%$, (2) false positives (understanding deficiency) as much as $9.8 \%$, and (3) false negatives (less information or careless) as much as $7.1 \%$. The study implies many attempts are needed to improve prospective mathematics teachers' conceptual understanding in geometry.
\end{abstract}

Keywords - misconception, geometry, prospective teacher, three tier diagnostic test

\section{INTRODUCTION}

There are four objects in mathematics, namely facts, concepts, operations and principles. In general, concepts can be divided into two types: (1) daily and scientific concepts [1]. The difference between every day and scientific concepts lies in the system that build the concept. The scientific concept growth in the history of human development in knowledge acquiringwhich usually tends to be abstract rather than concrete one.

Concepts in mathematics are considered as scientific concepts since it based on the system. It is usually used to enable a person to classify certain objects. Also, to find the examples and non-examples of the defined objects.

The study of Prayitno et al. [2] showed that the prospective mathematics teachers have numerous problems in their problem-solving abilities, especially in geometry topic. It was found that the students' low performance in problem-solving was caused by their inabilities to understand the context of certain problem which compounded by the lack of understanding in geometrical concepts. Here the students tend to mix the concepts from daily point of view and the scientific one which leads to misconception.

The concepts of geometry served in relational system. Hence, if a person was not master it as a whole holistic knowledge, there will be a misinterpretation of the concepts, the situation commonly known as misconception. The misconception in geometry concepts usually happened in students, prospective teachers and in-service teachers [3][11].

The misconception usually occurs if there is a gap between the students' level of thinking which is not exactly as it is recommended in van Hiele theorem [12]. Without any improvement in teaching and learning process, the misconception will persists into higher level of education, e.g. in university.

The misconception in university students' thinking process closely related to their low performance in communicating mathematical ideas [13] and problem solving [2]. It also created difficulties in learning advance mathematical concepts [14].

According to Hewson (in [15]), the students' misconception is resistant. Hence, if it is not fixed as early as possible, the misconception will be complex and stable. In other words, the upcoming concepts will be built in a wrong conceptual structure. To guide the students back to the correct concepts, teacher should provide a better lesson that enable students to re-thinking and debunking their previous believes.

Reflecting on the results of previous studies, it is clear that misconception is a serious problem. It will become extremely danger if it occurs in the prospective students since they will be teachers and suppose to support their students in acquiring correct mathematical concepts. Therefore, the present study aims to figure out what kind of misconception that happened in mathematics prospective teachers. The results of this study will be useful to give feedback to the teacher training institution in revitalizing the learning sources and activities to enhance the prospective teachers' conceptual understanding in mathematics.

\section{METHODS}

The $t$ present study was descriptive study with mixed method analysis between qualitative and quantitative [16] The quantitative data employed to categorize the students' geometry misconception while the qualitative data employed to describe the students' misconception and the reason behind it.

The misconception data were gathered from diagnostic test in geometry conceptual understanding. The type of diagnostic test performed was Three-Tier test developed by Arslan et al. [17]. The test was arranged from three levels, 
i.e. (1) conceptual question in form of multiple choice, (2) the reason to choose the choice in problem (1), also in multiple choice and one space provided if the student has different reason and (3) certainty or students' confidence in answering problems (1) and (2). The diagnostic instrument was validated by experts in mathematics education before it was used.

The subject of the study was 52 students of mathematics education study program in teacher training faculty of a university in Mataram, Indonesia. The data were gathered from students' responses in aforementioned diagnostic test. The data related to students' misconception category were classified as in Table 1 (as is suggested in Arslan er al. [17]).

TABLE 1: CATEGORY OF STUDENTS' RESPONSES BASED ON THREE-TIER DIAGNOSTIC TEST

\begin{tabular}{|l|l|l|l|}
\hline First Tier & Second Tier & Third Tier & Category \\
\hline Correct & Correct & Sure & Understand the Concept \\
\hline Correct & Incorrect & Sure & $\begin{array}{l}\text { Misconception (False } \\
\text { Positive) }\end{array}$ \\
\hline Incorrect & Correct & Sure & $\begin{array}{l}\text { Misconception (False } \\
\text { Negative) }\end{array}$ \\
\hline Incorrect & Incorrect & Sure & Misconception (Pure) \\
\hline Correct & Correct & Not Sure & Guessing \\
\hline Correct & Incorrect & Not Sure & $\begin{array}{l}\text { Not Understand the } \\
\text { Concept }\end{array}$ \\
\hline Incorrect & Correct & Not Sure & \\
\hline Incorrect & Incorrect & Not Sure & \multicolumn{2}{|l}{} \\
\cline { 1 - 2 } & & \multicolumn{2}{|l}{}
\end{tabular}

After got the category of students' misconception, the students' responses were described qualitatively to figure out what factors contribute to students' misconception.

\section{RESULTS AND DISCUSSION}

The data about students' misconception gathered from three-tier diagnostic test. The students were asked to work on ten questions related to geometry concepts. The students' responses were classified into four categories: (1) understand, misconception, (3) guess and (4) not understand the concept. The results (on percentage) can be observed in Fig.1.

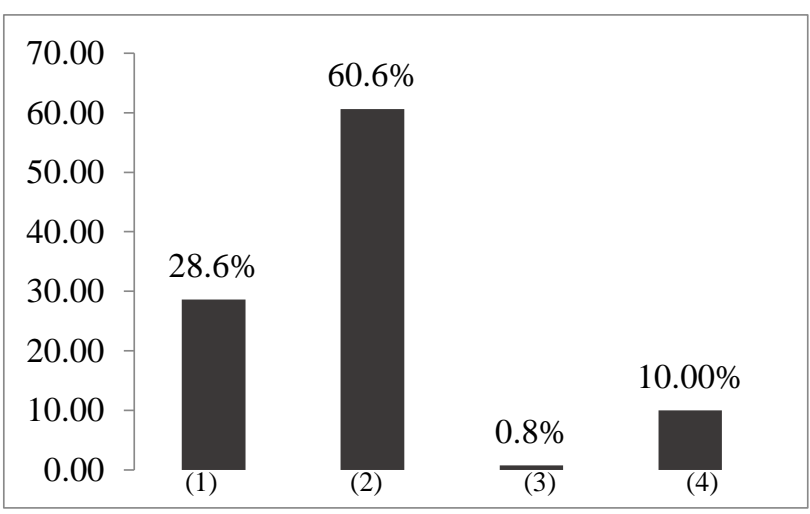

Fig.1. Students' Misconception in Geometry

Fig.1. illustrates that the majority of students encountered misconception. In general, the number of students who have no proper understanding in geometry concepts were approximately three times larger than the students who understand. Digging deeper, the students' misconception can be classified into three categories, i.e. pure misconception, false positive (if the student not fully understood the concept) and false negative (if the information was lacking) [17]. The detail about students' misconception can be seen in Table 2 .

TABLE 2: STUDENTS' MISCONCEPTION IN EACH CONCEPTS OF GEOMETRY

\begin{tabular}{|l|c|l|l|}
\hline \multirow{2}{*}{ Problem and Concept } & \multicolumn{2}{|c|}{ Category of Students' Responses } \\
\cline { 2 - 4 } & $\begin{array}{c}\text { Full } \\
\text { Misconception } \\
(\%)\end{array}$ & $\begin{array}{c}\text { False } \\
\text { Positive } \\
(\%)\end{array}$ & $\begin{array}{c}\text { False } \\
\text { Negative } \\
(\%)\end{array}$ \\
\hline $\begin{array}{c}\text { 1. Intersection of line and } \\
\text { quadrilateral }\end{array}$ & 48.1 & 7.7 & 1.9 \\
\hline $\begin{array}{l}\text { 2. Intersection of two } \\
\text { quadrilaterals }\end{array}$ & 69.2 & 1.9 & 1.9 \\
\hline 3. Parallel lines and angles & 63.5 & 17.3 & 3.9 \\
\hline $\begin{array}{l}\text { 4. The conceptual relation } \\
\text { among quadrilaterals }\end{array}$ & 71.2 & 1.9 & 0.0 \\
\hline $\begin{array}{l}\text { 5. Summary of Interior } \\
\text { Angles of a Polygon }\end{array}$ & 50.0 & 7.7 & 1.9 \\
\hline 6. Congruency of Triangles & 13.5 & 19.2 & 23.1 \\
\hline 7. Similarity of Triangles & 44.2 & 9.6 & 7.7 \\
\hline 8. Symmetry & 30.8 & 13.5 & 17.3 \\
\hline $\begin{array}{l}\text { 9. Comparison of volume } \\
\text { of cuboid }\end{array}$ & 36.5 & 7.7 & 9.6 \\
\hline 10. Net of Cube & 9.6 & 11.5 & 3.9 \\
\hline Average & 43.7 & 9.8 & 7.1 \\
\hline
\end{tabular}

Based on Table 2, it can be seen that the majority of students who encountered misconception were in pure category, which means the concepts built in their cognitive structure was incorrect. There are $43.7 \%$ from $60.6 \%$ of students who fall in this category. This result confirmed the previous study which stated that the pure misconception was the most common type of misconception occurred in students [18].

Furthermore, $9.8 \%$ students were in false positive. The students in false positive category means they correctly chose the concept but not the reason. Therefore, the students in false positive category is more likely to be guided into the fully mastered conceptual understanding level.

The first problem was asking about the intersection of rectangle and line. The students' common misconception was happened since they considered rectangle as a plane or picture in the paper. Hence, they thought the intersection will be a line segment or the line itself.

The similar case was also emerged in second problem. The question was about the shape of intersection occurred between rectangle and trapezoid. The students with misconception consider the rectangle and trapezoid as a plane. Therefore, they thought the intersection will be a quadrilateral. In Fig.2. the complete question for the second problem can be observed. 
Rectangle $\mathrm{ABCD}$ and trapezoid $\mathrm{PQRS}$ lied in the plane $\mathrm{V}$. They intersect as can be seen in the following figure. What is the shape of the intersection formed by the rectangle $\mathrm{ABCD}$ and trapezoid $\mathrm{PQRS}$ ?

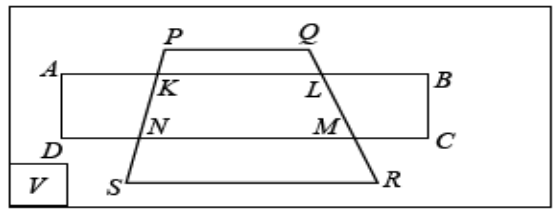

A. Trapezoid KLMN

B. Line Segments KN and LM

C. Plane KLMN

D. Points K, L, M, and N

Reason

A. Both rectangle and trapezoid are simple closed curves, therefore their intersection will be a simple closed curve as well.

B. Both rectangle and trapezoid are simple closed curves, therefore their intersection will be some points.

C. Both rectangle and trapezoid are two-dimensional shapes, therefore their intersection will be a two-dimensional shape.

D. Both rectangle and trapezoid are two-dimensional shapes, therefore their intersection will be some line segments.

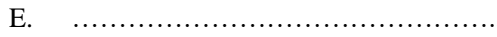

Are you sure with your answer and the reason you chose?

A. I am sure

B. I am not sure

Fig.2. Example of Problem in Three-Tier Diagnostic Test

The third problem was related to the geometry concepts of the pair of angles in transversal line. Here, the misconception was happened due to the incomprehensive or partial understanding of the topic. The similar case raised in the fourth problem when the students were asked to state the relation between the types of quadrilateral. Some questions in the fourth problem were: (1) Is a square a rectangle? (2) Is a parallelogram a rectangle? (3) Is a rectangle a parallelogram? (4) Is a trapezoid a parallelogram? The fourth problem is considered as the hardest for students. It can be observed from the percentage of students who face misconception, which was the highest from the total 10 geometry concepts measured in the present study.

The reason of the partial understanding of the concept is likely because of the separated instructional series of learning mathematics in the traditional classroom. Mathematics should be taught in spiral, within the connection between one to another topic. Without that, the students will hardly figure out the complete ideas of the concepts. The misconception usually started in earlier step of students' mathematics learning time, such as in elementary school level [19]. It continues as students learn in further educational stage and contributes to further misconception in geometry.

The relation among mathematical concepts also become the focus of the fifth problem. Here, the students should find the relation between the total interior angles in a triangle and in a irregular pentagon. The pure misconception for this problem was $50 \%$. It is happened due to students' difficulties in connecting their knowledge related to interior angles of triangle and manipulating the pentagon into three triangles according to its diagonals. The majority of students who encountered pure misconception $(42.8 \%)$ argued that the interior angles of a pentagon cannot be determined because the not all of the sides' length were equal. The students' argument indicated that they missled by the choices provided in the test. Furthermore, another interesting fact is, most of the students who correctly applying the concept were dividing the pentagon into two shapes, i.e. triangle and trapezoid. Afterwards, they added the total angles of those, i.e. $180^{\circ}$ and $360^{\circ}$.

The congruency and similarity concepts were asked in sixth and seventh questions. In Problem 6, the students worked with the comparison of sides in two congruent triangles. Here, the percentage of students who had pure misconception problem was relatively low (13.5\%) while $19.2 \%$ encountered false positive that can be fixed. In Problem 7, the students worked to solve the case related to corresponding sides in two congruent triangles. Here, $44.2 \%$ performed pure misconception while $9.6 \%$ encountered false positive. Reflecting to the result, the concept of congruency of the triangle sides were more understood by the students. It is because the daily life applications of the congruency concept appear to be more often rather than the context discussed in Problem 7.

The symmetry concept, line and rotation, were discussed in eighth problem. The misconception appeared here were not too high (pure misconception 30.8\% and false positive $13.5 \%$ ). The students are learning symmetry concepts since their elementary school level. Also, the problem was completed by an illustration that support the students to evaluate the line and rotation symmetries in a regular polygon.

The problem related to the simple three-dimensional shape which is cube, was highlighted in Problem 9 and Problem 10. The students encountered moderate pure misconception in the volume of cube (Problem 9) but performed good in net of cube (Problem 10). It can be seen from the lowest percentage of students encountered pure misconception in the last problem.

The students who did misconception in Problem 9 were mostly caused by over-simplifying the comparison of the volume by comparing the length of the sides. Meanwhile, to get the volume one should multiply the length of the sides three times, which means the comparison of the volume should also be the third power of the comparison of the sides.

As can be seen in the results above, misconception is one of the problems encountered by the prospective teachers. Particularly in geometry domain, the concepts of quadrilaterals, polygon and congruency need to be focused. To improve the prospective mathematics' teachers conceptual understanding, the course can be formatted into more student-centered setting. Previous studies showed one useful strategy is by implementing problem-based learning in which the lecturer can focus in enhancing the students' learning activities by providing scaffolding and limited guidance [20], [21] \& [22]. 


\section{CONCLUSION}

Based on the results and discussion, it can be concluded that majority of the students $(60.6 \%)$ encountered misconception in geometry concepts. Furthermore, $43.7 \%$ of the students had a pure misconception, while $9.8 \%$ encountered false positive misconception and $7.1 \%$ encountered false negative misconception. In general, the misconception happened due to the setting in teaching and learning mathematics in formal classroom which focused on the exercise of routine problems. Hence, the students did not learned the concepts deeply. The rest of the students were reported as having partial understanding (28.6\%) and answered the problem by guessing - no conceptual understanding $(10.8 \%)$. The results of the study can be used as feedback for the educators to focus on students' conceptual understanding development in learning mathematics.

\section{REFERENCES}

[1] Kaori, Y. 2004. Understanding How the Concept of Fraction Develops: A Vygotskian Perspective; Group for the Psychology of Mathematics Education, Proceedings of the 28th Conference of the International. Japan

[2] Prayitno, S., Kurniati, N., \& Saputra, I. 2018. Kemampuan Pemecahan Masalah Mahasiswa Calon Guru Matematika. Prosiding Seminar Nasional Saintek 2018 tanggal 27 Oktober 2018 di Lombok Plaza Hotel, ISBN: 978-602-53669-0-1, 539-547.

[3] Bieber, C., Tuna, A., \& Korkmaz, S. 2013. The Mistakes and the Misconceptions of the Eighth Grade Students on the Subject of Angles. European Journal of Science and Mathematics Education, Volume 1, No. 2, 50-59.

4] Irawan, E., Riyadi, \& Triyanto. 2012. Analisis Miskonsepsi Mahasiswa STKIP PGRI Pacitan pada Mata Kuliah Pengantar Dasar Matematika Pokok Bahasan Logika Ditinjau dari Gaya Kognitif Mahasiswa. Journal of Mathematics and Mathematics Education, Volume II, No. 1, 1-18.

[5] Fitria, A. 2014. Miskonsepsi Mahasiswa dalam Menentukan Grup pada Struktur Aljabar Menggunakan Certainity of Response Index (CRI) di Jurusan Pendidikan Matematika IAIN Antasari. Jurnal Pendidikan Matematika, Volume 1, No. 2, 45 - 60 .

[6] Sarlina. 2015. Miskonsepsi Siswa terhadap Pemahaman Konsep Matematika pada Pokok Bahasan Persamaan Kuadrat Siswa Kelas X5 SMA Negeri 11 Makassar. Jurnal Matematika dan Pembelajaran (MaPan). Volume 3, No. 2, 194-209.

[7] Ningrum, R. W., \& Budiarto, M. T. 2016. Miskonsepsi Siswa SMP pada Materi Bangun Datar Segiempat dan Alternatif Mengatasinya. MATHEdunesa, Jurnal Ilmiah Pendidikan Matematika, Volume 1, No. 5, 59-66.
[8] Johar, R., Fitriadi, Mahdalena, Rusniati. 2016. Miskonsepsi Siswa Sekolah Dasar pada Pembelajaran Bilangan Desimal. Jurnal Sekolah Dasar, Tahun 25, No. 2, 160-167.

[9] Julianto, E., \& Nurjamil, D. 2016. Analisis Subjek Matter Knowledge Calon Guru Matematika pada Topik Geometri. Jurnal Penelitian Pendidikan dan Pengajaran Matematika, Volume 2, No. 2, 179-188.

[10] Farida, A. 2016. Analisis Miskonsepsi Siswa Terhadap Simbol dan Instilah Matematika pada Konsep Hubungan Bangun Datar Segiempat Melalui Permainan dengan Alat Peraga. Prosiding Konferensi Nasional Penelitian Matematika dan Pembelajarannya, Universitas Muhammadiyah Surakarta, 12 Maret 2016, ISSN: 25026526, 286-295.

[11] Dzulfikar, A. \& Vitantri, C. A. 2017. Miskonsepsi Matematika pada Guru Sekolah Dasar. Suska Journal of Mathematics Education, Volume 3, No. 1, 41-48.

[12] Mistretta, R. M. 2000. Enhancing Geometric Reasoning. Adolescence, Volume 35, No. 138, 365-379.

[13] Prayitno, S. 2017. Profil Kemampuan Komunikasi Matematis Siswa SMP dalam Menyelesaikan Soal Matematika Ditinjau dari Perbedaan Gaya Kognitif dan Gender. Disertasi. Surabaya: Program Pascasarjana Universitas Negeri Surabaya.

[14] Dahar, R. W. 1996. Teori-teori Belajar. Jakarta: Erlangga.

[15] Sunarno, W. 1988. Model Remediasi Miskonsepsi Dinamika Menggunakan Animasi Simulasi Dengan Komputer. Disertasi. Bandung: PPs-UPI

[16] Sugiyono. 2009. Metode penelitian kuantitatif, kualitatif dan R\&D Bandung: Alfabeta.

[17] Arslan, H. O., Cigdemoglu, C., \& Moseley, C. 2012. A Three-Tier Diagnostic Test to Assess Pre-Service Teachers' Misconceptions about Global Warning, Greenhouse Effeect, Ozone Layer Depletion, and Acid Rain. International Journal of Science Education. Volume 34, No. 11, 1667-1686.

[18] Istiyani, R., Muchyidin, A., \& Rahardjo, H. 2018. Analisis Miskonsepsi Siswa Pada Konsep Geometri Menggunakan Three-Tier Diagnostic Test. Cakrawala Pendidikan. Th. XXXVII, No. 2, 223236

[19] Sarwadi, R., \& Shahrill, M. 2014. Understanding Students' Mathematical Errors and Misconceptions: The Case of Year 11 Repeating Students. Mathematics Education Trend and Research. doi:10.5899/2014/metr-00051, 1-10.

[20] R. D. Vale, "The value of asking questions," Mol. Biol. Cell, vol. 24, no. 6, pp. 680-682, 2013, doi: 10.1091/mbc.E12-09-0660.

[21] C. Chin and J. Osborne, "Students' questions: A potential resource for teaching and learning science," Stud. Sci. Educ., vol. 44, no. 1, pp. 1-39, 2008, doi: 10.1080/03057260701828101.

[22] I. N. Gita and R. A. Apsari, "Scaffolding in problem based learning to increase students' achievements in linear algebra," J. Phys. Conf. Ser., vol. 1040, no. 1, 2018, doi: 10.1088/1742-6596/1040/1/012024. 